\title{
AVALIAÇÃO DA QUALIDADE BACTERIOLÓGICA DA ÁGUA CONSUMIDA NO CAMPUS III (JARDIM BOTÂNICO) DA UNIVERSIDADE FEDERAL DO PARANÁ, CURITIBA, BRASIL.
}

\section{EVALUATION OF BACTERIOLOGICAL QUALITY OF WATER CONSUMED AT CAMPUS III (Botânico Branch) OF UNIVERSIDADE FEDERAL DO PARANÁ, CURITIBA, BRAZIL.}

\author{
Roberta Dotta Schazmann; Fabiana Menoncin; Eliane Rose Serpe Elpo² ; Eliane Carneiro \\ Gomes $^{2}$ \\ 1- Alunas voluntárias em Projeto de Pesquisa, Laboratórios das Disciplinas de Saúde \\ Ambiental e Saúde Pública 1, Curso de Farmácia, Universidade Federal do Paraná. Rua \\ Lothário Meissner, 632 - Jardim Botânico, Campus III, Curitiba - PR - Brasil. E-mail: \\ beta_ds@yahoo.com.br \\ 2 - Professoras da Universidade Federal do Paraná. Departamento de Saúde Comunitária. \\ Disciplina de Saúde Ambiental. Orientadoras da Pesquisa. \\ RECEBIDO: 12/06/08 ACEITO:15/07/08
}

\begin{abstract}
RESUMO:
O presente trabalho teve como objetivo avaliar a qualidade bacteriológica da água, destinada ao consumo humano, dos Setores de Ciências da Saúde, Ciências Sociais e Aplicadas e Ciências Agrárias (Sede Botânico), fornecida pela Companhia de Saneamento do Paraná (SANEPAR), e pelo único poço artesiano. A técnica utilizada foi a de fermentação de tubos múltiplos que determina o número mais provável (NMP) de bactérias coliformes em $100 \mathrm{~mL}$ de água. Os resultados obtidos para todos os pontos de coleta de água não registraram a presença de bactérias coliformes totais e termotolerantes em $100 \mathrm{~mL}$ de água analisada. Concluiu-se que sob o ponto de vista bacteriológico, esta água é adequada para o consumo humano, de acordo com a Portaria 518 de 25 de Março de 2004 do Ministério da Saúde. As análises foram realizadas no laboratório de Saúde Pública e Saúde Ambiental do Curso de Farmácia da Universidade Federal do Paraná.
\end{abstract}

Palavras-chaves: água, qualidade, bacteriológica.

\begin{abstract}
:
The present paper aims at evaluating bacteriological quality of water destined to human consumption supplied by Companhia de Saneamento do Paraná (SANEPAR) in the Health Sciences, Applied Social Sciences and Agrarian Sciences Sectors (Botânico Branch) as well as analyzing the water supplied by the only artesian. The technique used was to fermentation of multiple tubes that determines the most probable number (MPN) of coliform bacteria in $100 \mathrm{ml}$ of water. The results for all points of collection of water not recorded the presence of total coliform bacteria and thermotolerant in $100 \mathrm{ml}$ of water examined. It was concluded that from the point of view bacteriological, this water is suitable for human consumption, according to Ordinance 518, March 25, 2004 the Ministry of Health Analyses were performed in the laboratory of Public Health and Environmental Health of Course of Pharmacy, Federal University of Paraná. Key-words: water, quality, bacteriological.
\end{abstract}




\section{INTRODUÇÃO}

Elemento indispensável a todos os seres vivos, a água constitui o insumo essencial à preservação da vida no planeta, tanto que recobre três quartos da superfície terrestre, porém, para o consumo humano há apenas uma pequeníssima quantidade. Nos últimos anos vem-se verificando a crescente exploração dos recursos naturais, onde a água é o mais procurado e também o que mais tem sido afetado pela sua intensificação em função de sua utilização nos diversos campos. Para a água ser considerada apta para o consumo humano, ou seja, água potável, ela deve estar dentro dos padrões estabelecidos pela American Water Works Association (Batalha e Parlatore, 1993) e também pela legislação vigente em nosso país, a portaria 518 de 25 de março de 2004 do Ministério da Saúde (Brasil, 2004).

A água contaminada, segundo Riedel (1992), é capaz de veicular agentes infecciosos (bactérias, vírus, ovos ou larvas de helmintos) ou substâncias capazes de agredir a saúde humana. Por isso, para o controle de qualidade da água são feitos exames bacteriológicos ou microbiológicos, pois, nas águas, no ponto de vista sanitário, o que realmente põe em risco à saúde pública é a ocorrência de poluição fecal (Geldreich, 1974).

No entanto, a evidência direta daqueles agentes patogênicos na água é tecnicamente difícil. Por estes motivos, empregam-se métodos indiretos na investigação da presença ou não de poluição de origem fecal nas águas, pesquisando-se bactérias indicadoras de poluição fecal (Elpo et al., 2001). Estas bactérias pertencem ao grupo coliforme, que é composto pelos seguintes gêneros e espécies: Escherichia coli, Citrobacter freundii, Citrobacter intermedium, Enterobacter aerogenes, Enterobacter cloacae e Klebsiella pneumoniae (Brasil, 2004). São consideradas indicadoras de poluição fecal, pois estas bactérias estão presentes no trato intestinal humano e de outros animais de sangue quente e ausentes em animais de sangue frio, sendo eliminadas pelas fezes. $\mathrm{E}$ o corpo de água que recebe matéria fecal passa a ser potencialmente perigoso à saúde humana, pois, pode veicular agentes patogênicos intestinais, que são também eliminados habitualmente pelas fezes (Americam Water Works Association, 1992; Batalha e Parlatore, 1993).

O presente trabalho teve como objetivo analisar a qualidade bacteriológica da água, distribuída pela SANEPAR e pelo único poço artesiano existente no local e consumida pela comunidade acadêmica, no Campus III (Sede Botânico), da Universidade Federal do Paraná. O método empregado foi o de fermentação em tubos múltiplos que determina o número mais provável (NMP) de bactérias coliformes em $100 \mathrm{~mL}$ de água.

\section{MATERIAL E MÉTODOS}

A análise bacteriológica da água foi realizada nos meses de setembro e outubro de 2006, com amostras coletadas no Campus III - Jardim Botânico da Universidade Federal do Paraná, cuja metodologia utilizada é descrita pelo Standard Methods for Examination of Water and Wastewater segundo a American Water Works Association (1992) e Batalha e Parlatore (1993).

O procedimento da coleta, acondicionamento e preservação seguiram normas estabelecidas por Souza e Derísio (1977), e por Batalha e Parlatore (1993).

A amostragem compreendeu 22 pontos de coleta no Campus III (Sede Botânico) da Universidade Federal do Paraná, abrangendo todos os setores existentes neste mesmo local. Para a seleção dos pontos de coleta, considerou-se um levantamento prévio dos locais de maior consumo de água pela população acadêmica, como bebedouros, cozinhas e laboratórios nos Setores de Ciências da Saúde, Ciências Sociais e Aplicadas e Ciências Agrárias. 
Para o exame bacteriológico da água foi utilizado o método de tubos múltiplos de fermentação, também conhecido como determinação do Número Mais Provável (NMP) de bactérias coliformes totais e coliformes termotolerantes em $100 \mathrm{~mL}$ de água. O NMP corresponde a uma estimativa da densidade de bactérias coliformes pesquisadas a partir da combinação de resultados positivos e negativos (Batalha e Parlatore, 1993). O preparo dos meios de cultura empregados, caldo lauril triptose $(C L)$, caldo bile verde brilhante (VB) e meio de cultura para Escherichia coli (EC), seguiram as recomendações do fabricante.

As análises foram realizadas nos laboratórios das disciplinas de Saúde Pública e Saúde Ambiental do Curso de Farmácia da Universidade Federal do Paraná.

\section{RESULTADO E DISCUSSÃO}

Os resultados obtidos são apresentados na Tabela 1. Como não houve crescimento bacteriano em nenhuma das alíquotas correspondentes as amostras dos 22 pontos, o índice NMP/100 mL é $<1,1$, segundo o Standard Methods.

Neste trabalho, realizou-se apenas a prova de presunção, já que não houve formação de gás com turvação em nenhum dos tubos de $\mathrm{CL}$, dos 22 pontos de água coletados, após a incubação em estufa bacteriológica à $35^{\circ} \mathrm{C}$ por $24 / 48$ horas. Portanto, não houve necessidade de realizar a continuação do método de fermentação em tubos múltiplos, ou seja, a fase confirmativa e a completa. Isso indica que a água analisada nos 22 pontos mostrou-se própria para o consumo humano, do ponto de vista bacteriológico. Segundo a legislação vigente, a portaria 518 de 25 de março de 2004, do Ministério da Saúde, a água apta para consumo humano dentre outras especificações, não deve possuir bactérias do grupo coliforme por 100 $\mathrm{mL}$ de amostra. Desta forma, o resultado obtido indicou que o tratamento e armazenamento da água servida pela empresa SANEPAR, pelo poço artesiano existente no campus e pelas tubulações que conduzem esta água até a caixa de água, a manutenção e limpeza da caixa d'água estavam apropriadas, não permitindo a contaminação da água por esgoto ou qualquer fonte de bactérias coliformes de origem fecal.

A ausência de coliformes termotolerantes também é indicativa da inexistência de microorganismos patogênicos, os quais causam danos para a saúde humana, pois estas bactérias coliformes originam-se de fezes de animais de sangue quente, sendo as fezes a forma de contaminação de muitas patogenias (Rheinheimer, 1987). 
Tabela 1 - Análises bacteriológicas de amostras de água coletadas no Campus III da Universidade Federal do Paraná, Curitiba - Setembro a Outubro de 2006.

\begin{tabular}{|c|c|c|}
\hline \multirow[t]{2}{*}{ Local } & \multicolumn{2}{|c|}{$\mathrm{NMP}^{*}$ de coliformes $/ 100 \mathrm{~mL}$} \\
\hline & $\mathrm{CT}^{*}$ & CTE $^{*}$ \\
\hline Bebedouro (Farmácia) & $<1,1$ & $<1,1$ \\
\hline Cozinha (Farmácia) & $<1,1$ & $<1,1$ \\
\hline Lab.* de Técnica Dietética (Farmácia) & $<1,1$ & $<1,1$ \\
\hline $\begin{array}{l}\text { Lab. Síntese de Medicamentos Orgânicos } \\
\text { (Farmácia) }\end{array}$ & $<1,1$ & $<1,1$ \\
\hline Caixa d’água (Farmácia) & $<1,1$ & $<1,1$ \\
\hline Bebedouro (Nutrição) & $<1,1$ & $<1,1$ \\
\hline Cozinha (Nutrição) & $<1,1$ & $<1,1$ \\
\hline Lab. Avaliação Nutricional (Nutrição) & $<1,1$ & $<1,1$ \\
\hline Lab. Técnica Dietética (Nutrição) & $<1,1$ & $<1,1$ \\
\hline Lab. Tecnologia de Alimentos (Nutrição) & $<1,1$ & $<1,1$ \\
\hline Bebedouro (Administração) & $<1,1$ & $<1,1$ \\
\hline Cozinha (Administração) & $<1,1$ & $<1,1$ \\
\hline Bebedouro (Odontologia) & $<1,1$ & $<1,1$ \\
\hline Clínica Integrada I (Odontologia) & $<1,1$ & $<1,1$ \\
\hline Lab. de Prótese (Odontologia) & $<1,1$ & $<1,1$ \\
\hline Centro Cirúrgico (Odontologia) & $<1,1$ & $<1,1$ \\
\hline Bebedouro (Ciências Sociais e Aplicadas) & $<1,1$ & $<1,1$ \\
\hline Cantina (Ciências Sociais e Aplicadas) & $<1,1$ & $<1,1$ \\
\hline Bebedouro (Ciências Agrárias) & $<1,1$ & $<1,1$ \\
\hline Cantina (Ciências Agrárias) & $<1,1$ & $<1,1$ \\
\hline Caixa d’água (Ciências Agrárias) & $<1,1$ & $<1,1$ \\
\hline
\end{tabular}

*NMP(número mais provável); CT(coli

formes totais); CTE(coliformes termotolerantes);

Lab(laboratório).

Em 2001, Elpo, Gomes e Espínola, avaliaram 16 pontos de coleta, neste Campus III, Sede Botânico, nos mesmos laboratórios, utilizando a mesma técnica de fermentação da lactose em tubos múltiplos. O resultado obtido também foi a ausência de contaminação por coliformes totais e termotolerantes, mostrando que a água fornecida pela SANEPAR era de boa qualidade e também demonstrando que a manutenção e limpeza das cisternas e caixas d'água eram adequadas.

Por outro lado, a Universidade Estadual do Cento - Oeste (UNICENTRO) em Guarapuava, Paraná, avaliou a qualidade microbiológica das águas consumidas em 47 bebedouros do campus Cedeteg, proveniente de poços artesianos, e do campus sede, 
proveniente da rede de abastecimento público (SANEPAR), porém encontrou focos de poluição. Concluiu-se neste trabalho que $8,5 \%$ das amostras dos bebedouros do campus Cedeteg, estavam contaminados por coliformes totais e $2 \%$ por coliformes termotolerantes, ou seja, impróprias para consumo (Zulpo et al.,2006).

Também a qualidade microbiológica das águas de bebedouros da Faculdade de Medicina do Triângulo Mineiro apresentou contaminação em todos os bebedouros (prova presuntiva positiva), inclusive 3 das 4 amostras positivas estavam em desacordo com a legislação (Oliveira e Terra, 2004).

Além disso, analisou-se a água potável, cujas amostras forma oriundas de poços na cidade de Marília, SP, em 2001, em diversos locais da cidade. Coletaram-se as amostras em horários distintos com o intuito de fazer um comparativo entre as amostras de água em períodos diferentes do mesmo dia. O método empregado para esta análise foi o de "Colilert", mesmo método empregado pelo Departamento de Água e Esgoto de Marília (DAEM), o qual fiscaliza diariamente a água de abastecimento público da cidade. Somente uma das 18 amostras de água analisadas apresentou-se contaminada com coliformes totais, 1 bactéria por $100 \mathrm{~mL}$ de água, porém, nenhuma das amostras analisadas, apresentou contaminação por coliformes termotolerantes (Alves et al., 2002).

As análises realizadas pelo laboratório do Setor de Inspeção da Faculdade de Medicina Veterinária da Universidade Federal do Rio Grande do Sul, também obtiveram resultados que indicaram contaminação da água analisada. O método utilizado, igualmente foi o de fermentação em tubos múltiplos, onde se analisou um total de 92 amostras de água, sendo 23 da rede pública e 69 de poços (Bergmann et al. 2007). Apesar de não haver bactérias coliformes totais e termotolerantes nas amostras analisadas neste trabalho, é importante a continuidade da análise, pois segundo outros autores, a água analisada em Universidades, fornecidas por Empresas de Abastecimentos e captadas de poços artesianos são passíveis de contaminação fecal.

\section{CONCLUSÃO}

Os resultados obtidos para todos os 22 pontos de coleta de água analisadas, do Campus III, Sede Botânico, registraram valores inferiores a 1,1 bactérias coliformes totais e termotolerantes em $100 \mathrm{~mL}$ de água. Mostrando que, no ponto de vista bacteriológico, as amostras analisadas estavam próprias para o consumo humano, de acordo com a Portaria 518 de 25 de Março de 2004 do Ministério da Saúde. Portanto, concluiu-se também que a água fornecida pela SANEPAR recebeu tratamento adequado, assim como houve correta manutenção e limpeza das cisternas. A água do poço também se mostrou adequada para o consumo, indicando que não havia contaminação por coliformes totais e termotolerantes.

\section{AGRADECIMENTOS}

As autoras agradecem a todos servidores que gentilmente permitiram a coleta das amostras de água nas dependências de seus locais de trabalho. 


\section{REFERÊNCIAS}

ALVES, N.C.; ODORIZZI, A.C.; GOULART, F.C. Análise microbiológica de águas minerais e de água potável de abastecimento. Revista Saúde Pública, São Paulo, v. 36, n. 6, 2002.

AMERICAN WATER WORKS ASSOCIATION. Standard methods for examination of water and wastewater. 18.th. Washington: American Public Health Association, 1992.

BAtAlHA, B.; PARLATORE, A. C. Controle da Qualidade da Água Para Consumo Humano. Bases Conceituais e Operacionais. São Paulo: CETESB, 1993.

BERGMANN, G.P. et al. Análise microbiológica da água de agroindústrias, poços e rede pública da grande Porto Alegre. In: SALÃO DE EXTENSÃ̃, 7, 2007. Porto Alegre. Anais... Porto Alegre: Universidade Federal do Rio Grande do Sul (UFRGS), modalidade oral. Disponível em: www1.ufrgs.br/extensao/salaoextensao/mostra/vis_

acao_mostra.asp. Acesso em: dez. 2007.

BRASIL. Portaria n.518, 25 de Março de 2004. Estabelece os procedimentos e responsabilidades relativos ao controle e vigilância da qualidade da água para consumo humano e seu padrão de potabilidade, e dá outras providências. Disponível em: < http:// www.anvisa.gov.br/legis/index.htm>. Acesso em: 17 de abril de 2007.

ELPO, E.R.S.; GOMES, E.C.; ESPÍNOLA, H.M. Análise Microbiológica da Água na Universidade Federal do Paraná, Subsede do Setor de Ciências da Saúde, Jardim Botânico, Campus III. SANARE, Curitiba, v. 16, 2001.

GELDREICH, E.E. Aspectos microbiológicos dos esgotos e dos seus processos de tratamento. In: Companhia Estadual de Tecnologia de Saneamento Básico e de Controle de Poluição das Águas (Ed.). Desinfecção de águas. São Paulo: CETESB, 1974, p.115-134.

OLIVEIRA, A.C.S.; TERRA, A.P.S. Avaliação microbiológica das águas dos bebedouros do Campus I da Faculdade de Medicina do Triângulo Mineiro, em relação à presença de coliformes totais e fecais. Revista da Sociedade Brasileira de Medicina Tropical, Brasília, v. 37, p. 285286, 2004.

RHEINHEIMER, G. Microbiologia de Las Aguas. Zaragoga: Acribia, 1987.

RIEDEL, G. Controle sanitário de alimentos. 2.ed. São Paulo: Livraria Atheneu, 1992.

SOUZA, H.B.; DERISIO, J.C. Guia técnico de coleta de amostras de água. São Paulo: CETESB, 1977.

ZULPO, D.L. et al. Avaliação microbiológica da água consumida nos bebedouros da Universidade Estadual do Centro-Oeste, Guarapuava, Paraná, Brasil. Semina: Ciências Agrárias, Londrina, v. 27, n. 1, p.107-110, 2006. 